\title{
The Influence of Hedonic Motives and Browsing On Impulse Buying
}

\author{
Beyza Gültekin*, Leyla Özer \\ Hacettepe University, Beytepe-Ankara, Turkey \\ *beyza@hacettepe.edu.tr
}

\begin{abstract}
The purpose of this study is to investigate whether hedonic motives and browsing affect impulse buying and examine the role of browsing as a mediator between hedonic motives and impulse buying.In this context, a model was proposed and tested on a sample of customers who made an impulse purchase in Ankara. Confirmatory factor analysis supported the components of hedonic shopping motives such as adventure shopping, gratification shopping, role shopping, value shopping, social shopping, and idea shopping. Moreover, the results of the regression analysis showed that hedonic motives and its dimensions such as adventure, gratification, and idea have a positive impact on impulse buying. Consumers' browsing behaviorinfluenced impulse buying positively. The mediating role of browsing between hedonic motives and impulse buyingwas also identified.
\end{abstract}

Key Words: Consumer behavior, impulse buying, hedonic motives, browsing

\section{Introduction}

In addition to consumers' planned shopping decisions, consumers make unplanned shopping such asmaking impulse buying, sudden decisions without prior intention to buy. According to the results of a recent research, impulse buying accounts for $20 \%$ of all shopping activities in stores (Bell, Corsten, and Knox, 2009). Consumers making a decision to buy in the store are very common in many countries such asBrasil (88\%), the Netherlands (80\%), UK (76\%), Australia (70\%), and Belgium (69\%) (Hawkins, Mothersbaugh, and Best, 2009). It was found that $39 \%$ of all purchases made in the department stores, $62 \%$ of purchases made in discount stores (Prasad, 1975) and 60-70\% of purchases made in supermarkets are impulse buying. Accordingly, consumers can makethe decision to buy many products and/or brands in store. However, high percentages of consumers' decision to buy in the stores may not mean that the decision to buy is just because of in-store factors (Bell et al., 2009). In this context, taking into account the in store and out of store factors (i.e. consumers' hedonic motives, impulse buying tendency, pre-purchase mood, demographics etc.)affecting impulse buying is important for the managers. Accordingly, this study aims to investigate the influence ofin-store browsing behavior andout of store related factorssuch as consumers' hedonic motives on impulse buying. Consumer motives explain the why of consumer decision to buy. Hedonic motives direct the way for a person to buy for pleasure and/or enjoyment. Tuncer et al., (2008) emphasized the importance of pleasure and browsing in terms of consumers' shopping center preferences. As consumers go shopping with hedonic motives, they browse and purchase the product by impulse just because they like it without considering the results. (Jarboe and McDaniel, 1987).As the time consumers spend in a store increase, the amount money spent and the quantity of products bought increase (Iyer, 1989).

Erkip (2005) reported that consumers visitshopping centers to spend their spare time by browsing the store. Accordingly,customers visiting the stores with hedonic motives may stay at the store for longer periods, which may increase the possibility of a purchase without prior intention to buy. In this sense, instore activities are important to increase the possibility of the consumers' browsing. Browsing is a crucial concept for customers' store choice and time spent in the store. Moreover, in Turkey there are limited studies on browsing. Consequently,consumers' browsing behavior is important in terms of practical and theoretical perspective. This perspective reveals that today's marketing managers should give importance to strategies related to both in-store and out of store factors.Identification of those factors may help managers to allocate sufficientbudget toin-store and out of store activities and strategies. Thus,the focus of this study has four dimensions: (1) the influence of hedonic motives and hedonic motives factors such as adventure, gratification, role, value, social, and idea motiveson impulse buying, (2) the effect of hedonic motives on browsing, (3) the impact of browsingon impulse buying, and (4)the mediating role of browsing between hedonic motives and impulse buying.For those purposes, the study firstly explains the concepts ofimpulse buying, hedonic motives and browsing. Secondly, the influence of hedonic motives on impulse buying is revealed. Thirdly, the effect of hedonic motives on browsing and the influence of 
browsing on impulse buying are explained.In this framework, the mediating role of browsing between hedonic motives and impulse buying is investigated.

\section{Literature Review}

Hedonic Motives and Impulse buying: Hedonism emphasizes the basic philosophy of taking pleasure in life and avoiding sadness and sorrow(Murray, 1964). Hirschman and Holbrook (1982) describehedonicshopping as the fantasy and different types of emotional experience stemming from buying a product. Consumers might have fantasies about having a product(Baumeister et.al., 1994).Consumers may experience emotional arousal following a hedonic shopping experience. In view of that, hedonic shopping comprisesemotions such as cheer, jealousy, fear, passionandjoy. Emotions are the phenomenon that relates to motives (Hirschman and Holbrook, 1982). Moreover, Hirshman and Holbrook (1982) state that emotional arousal can be a basic consumer motive in some product categories as books, games, food, apparel sports activities and may result in hedonic shopping. As hedonic shoppers have different motives, those consumers are asserted to satisfy different types of expectations (Arnold and Reynolds, 2003). Babin, Darden and Griffin (1994) maintained that shopping has more meaning than just having that product.In order for retailers to be successful,retailers focus on the pleasure side of shopping because of the importance of the consumers' hedonic experience to gain competitive advantage. Although retailers are trying to differentiate themselves by means of pleasure, academically there are limited studies investigating consumers' shopping activities for hedonic motives and reasons (Arnold and Reynolds, 2003).In parallel to the hedonic motives concept Tauber (1972) does not consider shopping as just buying. Whether their perspective of shopping is just buying or not, consumers should go shopping just as they need a product. Conversely, consumers go shopping, as they want to spent time with friends, follow new trends and discounts, need sensory arousal and gratification, and engage in physical activity etc.i.e. for personal and social motives. Accordingly, Tauber (1972) views shopping beyond just purchasing a product. Arnold and Reynolds (2003) stated that hedonic motives resemble utilitarian motives, whichaims to make shopping an activity conducted to complete a task (i.e. shopping to buy vegetables to for household).

On the contrary, the mission of hedonic motives is to make consumers have fun, enjoyment, fantasy, and sensory arousal (Arnold and Reynolds,2003).Literature (Piron, 1991; Rook, 1987; Hausman, 2000) supports that impulse buying satisfies many hedonic desires. Moreover,Ramanathan and Menon (2006) assert that the reason behind impulse buying is hedonic gratification. Herabadi et al., (2009) found a significant relationship between hedonic motives and impulse buying.Arnold and Reynolds (2003) emphasize the importance of hedonic motives in terms of impulse buying and declare that there should be studies focusing on the relationship between the types and intensity of hedonic motives and impulse buying. In view of that, there are conceptual studies supporting the relationship between hedonic motives and impulse buying (Peck and Childers, 2006). Thus, Bloch and Richins (1983) states impulse buying is not just due toin-store promotional activities. Literature (Cobb and Hoyer, 1986; Hausman, 2000; Rook, 1987; Rook and Fisher, 1995; Thompson, Locander and Pollio, 1990; Ramanathan and Menon, 2006; Peck and Childers, 2006) recognizesthe influence of hedonic motives on impulse buying.Hedonic shopping motives related to shopping experience quality, which is associated with intention to buy (Wakefield and Baker, 1998). Moreover, Arnold and Reynolds (2003) state that hedonic motives are related to in-store experiences and customer satisfaction.As a result, consumers going shopping with hedonic motives may buy products without prior intention (Tauber, 1972). Therefore the following hypothesis is formed:

H 1. Hedonic motives affect impulse buying positively

Many studies classify consumers' shopping styles and/or motives in order to understand their tendencies during shopping (Puccinelli et al., 2009; Sproles and Kendall, 1986; Wesley, LeHew, and Woodside, 2006). Those classifications help to understand the reasons of different shopping behavior. In this context,this study uses the classification developed by Arnold and Reynolds (2003) such as adventure shopping, gratification shopping, role shopping, value shopping, social shopping, and idea shopping.Puccinelli etal., (2009) state that consumers who shop with adventure and idea shopping motives may search for sensory experiences.Differentiation motive occurs as the consumers describe shopping as a way to create a difference in their lives. Accordingly, consumers may take a break from their daily routine and spend their spare time pleasantly. Therefore, by means of impulse buying consumers may feel they are in another world, which is a sign of adventure shopping motives (Arnold and Reynolds, 2003). In addition, emotional states such as excitement, higher levels of pleasure, and stimulation are important since positive stimulation affects consumers' decision to buy (Wakefield and Baker, 1998). Stimulation theories 
existence is based on adventure shopping motives (Arnold and Reynolds, 2003). In other words, it was emphasizedsensory stimulation may create hedonic shopping value (Tauber, 1972; Westbrook and Black, 1985, Babin et al., 1994). In this regard,

H1 a. Adventure motives affect impulse buying positively

O'Shaughnessy (1987) stated that emotions affect consumers' purchasing behavior, and strengthen motives. Babin et al.,(1994) affirmthat participants declared their desire to go shopping when they are sad. In view of that, consumers' emotions can turn into motives and that motivation directs consumers to go shopping (Babin et al., 1994).Hausman (2000) asked participants to tell their shopping experiences as follows: "So yeah, basically it does make me feel better. I shop to pass the time and to visit friends and, on occasion, to check out new items in the store, but mostly to pass thetime. Because, after a busy work day, sometimes I like to relax and walk up and down aisles of stores." "I like to go to the mall or some of the little shops. For me, it's therapy. Just gettinginto the department stores, into the mall is therapy. And I'll probably spend thesame amount as going to a therapist, so it doesn't matter. Shopping is therapy."In line with the mentioned interviews (Hausman, 2000)view Tauber (1972) stress the importance of shopping as a way to relief and gratification. Consumers who experience boredom have the intention to buy when the shopping experience is good (Puccinelli et al., 2009). Many studies emphasize the fact that consumers feel better and full of energy after impulse buying (Cobb and Hoyer, 1986; Rook, 1987; Hausman, 2000). In addition, pleasure and surprise concepts are related to impulse buying (Hausman, 2000).

H1 b. Gratification motives affect impulse buying positively

Tauber (1972) declared that many consumer activitiesstem from social norms (i.e. expectations of the society and learned behavior). Those learned behaviors are related to the roles that consumers play as a mother, housewife and student in the society. Those consumers are motivated to shop according to those roles. Moreover, consumers who shop with role shopping motives feel the pleasure of shopping for others (Arnold and Reynolds, 2003). Accordingly, consumers, who shop with role shopping motives tend to feel better and pleasure by means of impulse buying.

H1 c. Role motives affect impulse buying positively

Consumers, with value shopping motives pay attention to in-store promotions (i.e. price discounts) (Arnold and Reynolds, 2003). Accordingly, consumers gain hedonic benefits from discounts by means of excitement and sensory involvement (Babin et al., 1994). One of the participants in research carried out byBabin et al., (1994) explained his impulse buying as being a result of discounts. In this context, discounts resulting in impulse buying may be because of the hedonic benefit received. In addition, Bucklin and Latin (1991) declare that in-store activities such as sales promotions (i.e. price discounts) may influence consumers' unplanned buying decisions. In other words, consumers who are affected by price discounts tend to make unplanned buying. Cox, Cox and Anderson (2005)stress that in the literature there are limited studies on discount oriented consumers. Price-sensitive, 'economic' consumers do not like shopping, consumers who shop for pleasure do not focus on the price(Bellenger and Korgaonkar, 1980). On the other hand, Cox et al., (2005) assert that low price is not only related to cognition but also to emotional satisfaction. Moreover, consumers who buy products with price discounts show emotional reactions such as feeling proud of themselves, a sense of achievement (Schindler, 1989; Mano and Eliot, 1997; Cox et al., 2005), feeling smart (Schindler, 1989; Cox et al., 2005), and excitement (Mano and Eliot, 1997; Cox et al., 2005).

H1 d. Value motives affect impulse buying positively

According to Cox et al., (2005)as consumers shop they may be close to other consumers and some of them search for social interaction. Some of the consumers want other consumers, sales representatives, friends and/or relatives to be with them while they are shopping (Westbrook and Black, 1985; Cox et al., 2005). Moreover, places where consumers shop can be regarded as traditional social activity centers (Tauber, 1972).Hausman (2000) states that according to Maslow (1968) social needs may be related to impulse buying since consumers unconsciously tell their social motives during interviews while talking about their impulse buying experiences. Hausman (2000) also added that since the reliability of social motive measure was low, that relationship should be tested again.

H1 e.Social shopping motives affect impulse buying positively

Tauber (1972) claim that consumers regard products as symbols reflecting their attitudes and lifestyles. For that reason, products may be a part of consumers' life. In addition, innovativeness, which can be a consumer lifestyle,is considered to beamong the factors affecting impulse buying (Hausman, 2000). That 
perspective is supported by a participant interviewedafter shoppingdescribing himself as being on duty to find something "different", the product that no one has (Hausman, 2000). In this vein, many consumers are interested in different products, new items, and styles and update trends. Hence, some consumers without prior intention to buy see a new product and may make impulse buying.

$H 3 f$. Idea shopping motives affect impulse buying positively

Hedonic Motives and Browsing: Many consumers without any intention to buy go shopping just because they want to get out of their house or office (Berman and Evans, 2007). In this regard, Bloch et al., (1989) reported that although shopping is regarded as just buying a product,it can be described as buying, information gathering, and pleasure. Therefore, in addition to buying consumers go shopping to spent time by browsing in order to get information about the products and their prices etc. (Bloch et al., 1989). Hence, browsing is consumers' examination of window displays (Jarboe and Mc Daniel, 1987) and products (Bloch and Richins, 1983; Bloch et al., 1989) without prior intention to buy just for pleasure and/or information gathering (Bloch and Richins, 1983; Bloch et al., 1989). Moe (2003) stressed that consumers without prior intention to buy can make "hedonicbrowsing"who are motivated by hedonic benefits from their shopping experience. In view of that hedonic browsing is experimental and mostly result in impulse buying (Moe, 2003).Bloch and Richins (1983) stated that consumers who browse have more knowledge in terms of product category compared to non-browsers.In addition, due to the enhancement of browsers' knowledge in products and market their curiosity motives are satisfied (Moe, 2003). Browsing contributes to self-esteem (Bloch and Richins,1983). In addition, browsers can attract peers and can be trend-setters (Jarboe and McDaniel, 1987).

Beatty and Ferrell (1998) stated that individual and situational factors affect browsing. Studies (Jarboe and McDaniel, 1987; Bloch et al., 1989;Cox et al., 2005) emphasize the effect of hedonic motives on browsing (Arnold and Reynolds, 2003).One of the reasons for browsing is to satisfy pleasure motives (Bloch et al., 1986).Consumers shopping with hedonic motives like browsing (Chebat, Gélinas-Chebat, and Therrien, 2005) and take pleasure in examining visual elements in the retailers (Cox et al., 2005). Parallel to this view, Kim and Kim (2008) add that consumers who like shopping compared to ones who do not, have greater tendency to browse. Many motives such as differentiation, sensory stimulation and social interaction (Tauber, 1972) are related to the concept of shopping without purchase such as for pleasure and information gathering shopping (Bloch and Richins, 1983). Accordingly, consumers who view shopping as pleasure are regarded as consumers who allocate more time to shopping and are searching for information (Bellenger and Kargoankar, 1980; Bloch and Richins, 1983). This perspective reveals that browsing is important for retailers (Bloch et al., 1989). As the time consumers spend in a retailer increases, their amount and possibility of spending will increase (Donovan et al., 1994; Wakefield and Baker, 1998). In other words, consumers without an intention to buy can patronage a store and while browsing the products, consumers can make impulse purchase (Bloch et al., 1989).Additionally, Hirschman (1980) reported that some buying activities can be utilitarian and others could stem from hedonic motives. Although Bloch etal., (1986) asserted that in consumers' daily life those two motives are interrelated; the study found that hedonic motives affect browsing more.

H2. Hedonic motives affect browsing positively

Browsing and Impulse Buying: The formation of modern transportation systems and increase the amount of consumers' spare time and result in increased consumer mobility (Tauber, 1972). Because of those reasons, consumers may prefer to go shopping in their free time. Consumers' allocated time for browsing and amount of purchase they make are positively related (Iyer, 1989). Moreover, the time spentfor browsing increases the amount of exposure. As the period of exposure increases, possible stimulation affect of the product may increase and consumers may feel how much they need that product (Jarboe and McDaniel, 1987).Parallel to this view browsing occurs as a result of exposure to a stimulus not as a result of buying motive (Moe, 2003). Bellenger et al., (1978) reported that browsing can be a reason of sudden unplanned behavior. In addition, Rook (1987) identified that after consumers browse, they feel a sudden and strong urge to buy. Parallel to this finding, Park and Lennon (2006) declare that consumers can make impulse purchase after browsing in the shopping center or through store corridors.According to Bloch et al., (1989), consumers without intention to buy something from a store may enter a store and and may make impulse buying (Jarboe and McDaniel, 1987; Bloch et al., 1989; Beatty and Ferrell, 1998) while browsing when exposed to in-store promotions and new products (Bloch et al., 1989). Thus,browsing behavior of consumers in stores or consumers' window-shopping can affect impulse buying.

H3.Browsing affects impulse buying positively 
In the literature browsing acts as a mediator between many variables (i.e. shopping pleasure and urge to buy) (Beatty and Ferrell, 1998). In this study,the mediating role of browsing can be formulated as a hypothesis based on the theoretical background in the formation of H1, H2 and H3 (Baron and Kenny, 1986).

H4. Browsing is a mediator between hedonic motives and impulse buying

According to the hypotheses formed, the theoretical model is given on Figure 1.

\section{Figure 1:The Theoretical Model forthe Factors Affecting Impulse Buying}

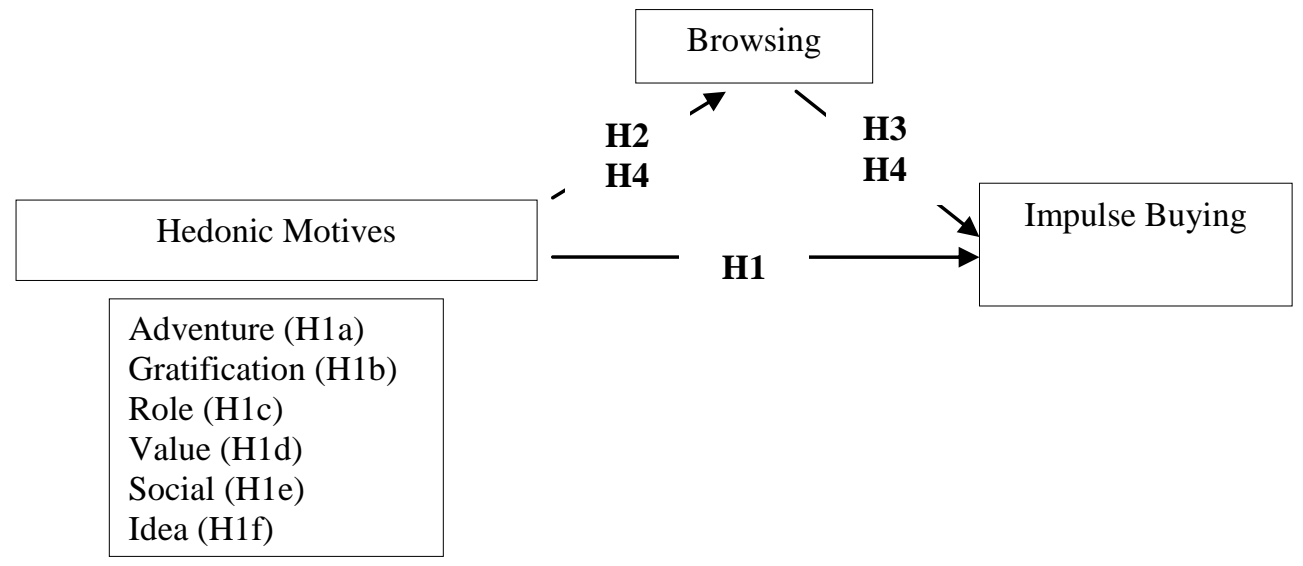

\section{Methodology}

Sample and Measures: This study formed hypotheses and accordingly conducted a survey by using nonprobabilistic convenience sampling in different regions in Ankara, Turkey.Hair et al., (2006) stated that the sample should be based on the analysis conducted. In this study to validate the dimensions of the hedonic motives such as adventure, gratification, role, value, social, and idea shopping motives,initially, confirmatory factor analysis was conducted. In addition, regression analyses were conducted to test the influence of hedonic motives on impulse buying and browsing; browsing on impulse buying. Moreover, to test the mediation role of browsing between hedonic motives and impulse buying, Baron and Kenny (1986)'s steps were followed by performing regression analyses.According to Hair et al., (2006), the sample size suitable to conduct confirmatory factor analysis is at most 400. Although the sample size above 400 may weaken the goodness of fit statistics ofthe model, a model above 6 variables can use a sample size of more than 500 (Hair et al., 2006). Since there are 6 variables to validate the dimensions of hedonic motives,a sample size of more than the 400 at most mentioned could be used. In this research 420 surveys were regarded as valid out of 450 because of missing answers, exactly same codification, etc.(Gültekin, 2010).To make the participants' responses more precise, in addition to which product they bought on impulse, they were asked the brand name, the store name and region. To measure hedonic motives the scale developed by Arnold and Reynolds (2003) is used. Browsing scale was adapted from Beatty and Ferrell (1998). The scale adapted from Asugman and Cote (1993) measured impulse buying, which is the dependent variable of this study. All of the scales used 7-Likert type to measure the participant agreement to those statements.

In order to prepare the data for the following analyses firstly outliers were eliminated. Since those were lower than $5 \%$ of the participants' answers, the mean values could be taken part for the outliers. Data shows normality according to the skewness and kurtosis values' being between \pm 3 (Shao, 2002). Although the data have not been collected by probabilistic sampling techniques, it can be regarded as random by applying runs test (Kavak, 2008). The fact that runs analysis results were insignificant revealed that the data is randomly collected.Pretest was conducted to test the reliability of the scales adapted. Pretest results showed all of the scales except browsing were reliable (cronbach alpha $>0.60$ ). According to the results of thefactor analysis (KMO $=0.518 ; \mathrm{p}<0.001$ ) conducted, first statement of the browsing scale "The percent of time I spent just looking around on the trip was fairly high." has been chosen as a surrogate variable with highest factor loading (0.749) (Hair etal., 2006)In addition, demographic structure of the sample was identified by questions regarding the participants' gender, age, 
income and educational level.Participants' demographic variables considering sample size and their percentages were given in Table 1.

Table 1:Demographics of the Participants

\begin{tabular}{llllll}
\hline Variables & $\mathbf{N}$ & $\mathbf{\%}$ & Variables & $\mathbf{N}$ & $\mathbf{\%}$ \\
\hline Gender & & & $\underline{\text { Education }}$ & & \\
Female & 235 & 56 & High school & 23 & 5.5 \\
Male & 185 & 44 & $\begin{array}{l}\text { Undergraduate } \\
\text { Graduate }\end{array}$ & 631 & 78.8 \\
& & & $\underline{\text { Income }}$ & & 15.7 \\
Age & & & & & \\
& & & Very Low & 14 & 3.3 \\
$18-28$ & 295 & 70.2 & Low & 41 & 9.8 \\
$29-38$ & 83 & 19.8 & Medium & 312 & 74.3 \\
$39-48$ & 26 & 6.2 & High & 53 & 11.7 \\
$49-58$ & 11 & 2.6 & Very High & 4 & 1 \\
$59+$ & 5 & 1.2 & & & \\
\hline
\end{tabular}

\section{Results and Analysis}

Based on these data, firstly, in order to test the effect of hedonic motives on impulse buying the dimensions of hedonic motives (i.e. adventure, gratification, role, value, social, and idea shopping motives)identified by performing confirmatory factor analysis. Analysis results reveal that for all variables t-values are above 1.96. Accordingly, parameter values are $95 \%$ significant. The confirmatory factor analysis regarding hedonic motives shows a good fit $\left(\chi 2=467.48 ; \mathrm{df}=221 ; \chi^{2} / \mathrm{df}=2.11\right.$; RMSEA= .052 , $\mathrm{CFI}=.96$; $\mathrm{NNFI}=.95 ; \mathrm{GFI}=0.91$; AGFI $=0.88$ ). In view of that goodness of fit statistics and values given in Table 3 it can be concluded that hedonic motives scale validity is acceptable. In other words, hedonic motives in parallel to research carried out byArnold and Reynolds (2003) are composed of adventure, gratification, role, value, social and idea shopping motives. According to confirmatory factor analysis results, the values of the factors are averaged to test the hypotheses.Table 2 gives reliability, mean and standard deviations of the variables.

Table 2: Reliability, mean and standard deviations of the variables

\begin{tabular}{llll}
\hline Variables & Reliability & Mean & $\begin{array}{l}\text { Standard } \\
\text { Deviation }\end{array}$ \\
\hline Hedonic Motives & 0.85 & 4.42 & 1.24 \\
Adventure Motives & 0.82 & 3.98 & 1.65 \\
Gratification Motives & 0.91 & 4.50 & 1.88 \\
Role Motives & 0.87 & 4.97 & 1.65 \\
Value Motives & 0.90 & 5.09 & 1.57 \\
Social Motives & 0.90 & 4.06 & 1.77 \\
Idea Motives & 0.86 & 3.91 & 1.68 \\
Browsing & na & 3.34 & 1.84 \\
Impulse Buying & 0.67 & 4.44 & 1.22 \\
\hline
\end{tabular}

Regression analysis was conducted to test the influence of hedonic motives on impulse buying. Dimensions of hedonic motives were averaged to test this effect. It was found that hedonic motives $(B=$ $0.448)$ significantly affected impulse buying $\left(R^{2}=0.211 ; F=111.502 ; \mathrm{p}<0.001\right)$. According to this result, $\mathrm{H} 1$ is supported. To test the influence of hedonic motives' factors on impulse buying regression analysis was performed. Results showed that adventure $(B=0.210 ; p<0.001)$, gratification $(B=0.111 ; p<0.01)$ and idea $(B=0.108 ; p<0.01)$ motives significantly increased impulse buying $\left(R^{2}=0.264 ; F=24.689\right)$, which supported H1a, H1b, and H1f. Role, value and social shopping motives did not have an influence on impulse buyingin this sense, $\mathrm{H} 1 \mathrm{c}, \mathrm{H} 1 \mathrm{~d}$, and $\mathrm{H} 1 \mathrm{e}$ rejected. To test the influence of hedonic motives on browsing regression analysis was conducted. This analysis results revealed that hedonic motives $(\mathrm{B}=$ $0.448)$ influenced impulse buying significantly $\left(R^{2}=0.264 ; F=24.689\right)$. In this sense, $H 2$ was supported.The impact of browsing on impulse buying was tested by performing regression analysis. Regression analysis results showed that browsing had an impact on impulse buying, which supported H3.To test the mediating role of browsing between hedonic motives and impulse buying, Baron and Kenny (1986)'s approach was followed. Firstly, three regression analysesshould be significant such as the 
effect of hedonic motives on impulse buying, hedonic motives on browsing, and browsing on impulse buying. These analyses wereconducted abovesupporting H1, H2, and H3, which creates a basis for mediator analysis. Secondly, according to Baron and Kenny (1986)'s approach,another regression analysis was conductedto test the influence of hedonic motives and browsing on impulse buying. The results showed that hedonic motives $(B=0.412 ; p<0.001)$ and browsing $(B=0.080 ; p<0.01)$ affected impulse buying positively and significantly $\left(\mathrm{R}^{2}=0.224 ; \mathrm{F}=60.063\right)$. These results supported theidea of the mediator role of browsing by the reduction of the unstandardized beta coefficients $\left(\mathrm{B}_{\mathrm{Hed}}=0.448\right.$ 0.412 ) as summarized in Table 3. In addition, since the effect of hedonic motives and browsing on impulse buying was significiant, partially mediation occured.

Table 3:Hypotheses Testing: Regression Analyses Results

\begin{tabular}{lllll}
\hline & \multicolumn{1}{c}{$\mathbf{B}$} & \multicolumn{1}{c}{$\mathbf{R}^{2}$} & \multicolumn{1}{c}{$\mathbf{F}$} & Results \\
\hline Hedonic Motives $\rightarrow$ Impulse Buying (H1)* & 0.448 & 0.211 & 111.502 & Supported \\
Hedonic Motives $\rightarrow$ Browsing (H2)* & 0.453 & 0.095 & 43.658 & Supported \\
$\begin{array}{l}\text { Browsing } \rightarrow \text { Impulse Buying (H3)* } \\
\text { Hedonic Motives-Browsing } \rightarrow \text { Impulse Buying } \\
\text { (H4) }\end{array}$ & 0.166 & 0.062 & 27,811 & Supported \\
P & & 0.224 & 60.063 & Supported \\
\end{tabular}

$\mathrm{P}<0.001$

\section{Discussion}

The purpose of this study is to investigate whether (1) hedonic motives and factors of hedonic motives such as adventure, gratification, role, value, social, and idea motives have an influence on impulse buying, (2) hedonic motives influences browsing (3) browsing affects impulse buying (4)browsing has a mediating role between hedonic motives and impulse buying. For these purposes,a survey was conducted witha sample of 420 customerswho made impulse purchase from one of the store-based retailers in Ankara. According to the analysis results, hedonic motives have an impact on impulse buying. Literature suggests that, whenconsumers' emotions are dominant on their cognition (Allen, Machleit and Kleine, 1992; Mano and Oliver, 1993; Herabadi et al., 2009) and/ordesires over their willpower (Hirschman and Holbrook, 1982; Hoch and Loewenstein, 1991; Ramanathan and Menon, 2006) impulse buying occurs. According to the literature (Herabadi et al., 2009; Ramanathan and Menon, 2006)desires are connected to the motivation system. In view of that, the influence of hedonic motives on impulse buying is in parallel with the literature (Piron,1991; Herabadi et al. 2009).Moreover, the influence of hedonic motives such as adventure, gratification, role, value, social, and idea motives on impulse buying are tested. The hypothesis asserting the impact of adventure, gratification and idea motiveson impulse buying is supported. Hence, as consumers go shopping with adventure, gratification, and idea motives their possibility to make an impulse purchase will increase. Consumers shopping with adventure, idea (Puccinelli et al., 2009) and gratification (O'Shaugnessy, 1987; Babin et al., 1994; Cobb and Hoyer, 1986; Rook, 1987; Hausman, 2000; Puccinelli et al., 2009; Tauber, 1972) motives might seek sensory experiences. This experience is in parallel with impulse buying literature (Wood, 1998, Rook, 1987, Hawkins et al., 2009) mentioning consumers' purchase withintense emotions, sudden and strong urge to buy. On the other hand, role, value and social motives did not have an effect on impulse buying.

This study supported the hypothesis formed to test the impact of hedonic motives on browsing. In this sense, results of the study can be interpreted to be consistent with the previously mentioned literature; consumers may browse without any intention to buy just for fun or pleasure. Moreover, the hypothesis asserting the effect of browsing on impulse buyingwas supported. This result is parallel with the literature suggesting a positive relationship between the amount of time spent in the store and the amount of money spent in the store (Donovan, Rossiter, Marcoolyn and Nesdale, 1994; Wakefield and Baker, 1998).In this context, hypothesis concerning the mediating role of browsing between hedonic motives and impulse buying was also supported.In other words, hedonic motives influence browsing which in turn influences impulse buying. Consumers who went shopping without prior intention to buywere influenced when browsing windows and products, which resulted in impulse buying. This implication is consistent with the Beatty and Ferrel (1998)'s study supporting the mediating role of browsing between shopping pleasure and feeling an urge to buy which resulted in impulse buying.

Limitations and Further Research: A survey was conducted with a sample of consumers who made impulse buying from store-based retailers in Ankara. Although the data collected shows a normal distribution 
and randomness, the survey was conducted in one city and store-based retailers. Further research can overcome this limitation by taking into account other cities or countries and other types of retailers such as non store-based retailers.There are many factors (i.e. product, price, place, promotion factors related to firm and consumers' impulse buying tendency, mood, demographics, available time, money and credit card) affecting impulse buying that could not be tackled inin this study and can be a topic for more comprehensive research in the future. Future studies may emphasize more specific concepts such as the influence of brand, product package, psychological pricing, and duration of the promotion, product display, allocated shelf to a product on impulse buying, which are stated as crucial investments in terms of store and out of store marketing strategies. There are limited studies on browsing. Browsing scale can be developed according to its dimensions such as information gathering to make a purchase in the future and just for "spending spare time" or "pleasure". Another limitation of this study is that it does not investigate the post purchase stage, which can also be examined. Some of the factors of hedonic motives can be related to "product" satisfaction and others to "shopping process" satisfaction, which can be another issue of research.

\section{Managerial Implications}

Consumers going shopping with hedonic motives have the potential to make an impulse purchase. For this reason store, managers should work towards being in the store choice set of those consumers. Store managers benefit from especially focusing on consumers with adventure, gratification and idea motives by emphasizing the elements such as "excitement", "pleasure", and "innovativeness" at the store. By instore activities such as arranging contests, allocating gifts, and creating better store atmosphere, managers can make consumers feel more excited and positive. Fashionable or new products launched should be on window displays and be at the level of eyes or hands on the displays in the stores to attract the consumer. Briefly, managers should make investments to in-store marketing activities to make consumers with hedonic motives choose and make them browse in that store. This situation supports the Engel et al., (1990)'s statement thatthe war of marketing strategiesis won and lost at the point-ofpurchase. Accordingly, managers should pay attention to in-store layout and promotional activities that are going to be performed.

\section{References}

Allen, C. T., Machleit, K. A.\& Kleine, S. S. (1992). A Comparison of Attitudes and Emotions as Predictors of Behavior at Diverse Levels of Behavioral Experience. Journal of Consumer Research, 18(4), 493504.

Arnold, M. J.\& Reynolds, K. E. (2003). Hedonic Shopping Motivation. Journal of Retailing, 79(2), 77-95.

Asugman, G.\& Cote, J. (1993). Cognitive and Affective Decision Making Preferences in Impulse Buying. Asian Journal of Marketing, 2(1), 23-30.

Babin, B. J., Darden, W. R.\& Griffin, M. (1994, March). Work and/or Fun: Measuring Hedonic and Utilitarian Shopping Value. Journal of Consumer Research, 20, 644-656.

Baron, R. M.\& Kenny, D. A. (1986). The Moderator-Mediator Variable distinction in Social Psychological Research: Conceptual, Strategic, and Statistical Considerations. Journal of Personality and Social Psychology, 51(6), 1173-1182.

Baumeister, R. F., Heatherton, T. F.\& Tice, D. M. (1994). Losing Control, How and Why People Fail at Self Regulation. San Diego, CA: Academic Press, Inc.

Beatty, S. E.\& Ferrell, M. E. (1998). Impulse Buying: Modeling its Precursors. Journal of Retailing, 74(2), 169-191.

Bell, D. R., Corsten, D.\& Knox, G. (2009). Unplanned Category Purchase Incidence: Who Does It, How Often, and Why. February 27, 2012, Working Paper.http://knowledge.wharton.upenn.edu/papers/1357.pdf

Bellenger, D. N.\& Korgaonkar, P. K. (1980). Profile the Recreational Shopper. Journal of Retailing, 56(3), 77-92.

Bellenger, D. N., Robertson, D. H.\& Hirschman, E. C. (1978). Impulse Buying Varies by Product. Journal of Advertising Research, 18, 15-18.

Berman, B.\& Evans, J. R. (2007). Retail Management a Strategic Approach. New Jersey: Pearson Education.

Bloch, P. H.\& Richins, M. L. (1983). Shopping Without Purchase: An Investigation of Consumer Browsing Behavior. Advances in Consumer Research, 10, 389-393.

Bloch, P. H., Ridgway, N. M.\& Sherrell, D. L. (1989). Extending the Concept of Shopping: An Investigation of Browsing Activity. Journal of the Academy of Marketing Science, 17(1), 13-21. 
Bloch, P. H., Sherrell, D. L.\& Ridgway, N. M. (1986). Consumer Search: an Extended Framework. Journal of Consumer Research, 13(1), 119-126.

Bucklin, R. E.\& Lattin, J. M. (1991). A Two-State Model of Purchase Incidence and Brand Choice. Marketing Science, 10(1), 24-39.

Chebat, J. C., Gélinas-Chebat, C.\&Therrien, K. (2005). Lost in a Mall, the Effects of Gender, Familiarity with the Shopping Mall and the Shopping Values on Shoppers' Way Finding Processes. Journal of Business Research, 58(11), 1590-1598.

Cobb, C. J.\& Hoyer, W. D. (1986). Planned versus Impulse Purchase Behavior. Journal of Retailing, 62(4), 384-408.

Cox, A. D., Cox, D.\& Anderson, R. D. (2005). Reassessing the Pleasures of Store Shopping. Journal of Business Research, 58(3), 250-259.

Donovan, R. J., Rossiter, J. R., Marcooly, G.\& Nesdale, A. (1994). Store Atmosphere and Purchasing Behavior. Journal of Retailing, 70(3), 283-294.

Engel, J. F., Blackwell, R. D.\& Miniard, P. W. (1990). Consumer Behavior (6th Ed.). USA: Dryden Press.

Erkip, F. (2005). The Rise of the Shopping Mall in Turkey: The Use and Appeal of a Mall in Ankara. Cities, 22(2), 89-108.

Gültekin, B. (2010). Utilitarian-Hedonic Motives, Browsing, and Brand Familiarity's Effect on Impulse Buying: A Model Proposal; Ph.D. Dissertation. Ankara, Turkey: Hacettepe University.

Hair, J. F., Black, W. C., Babin, B. J., Anderson, R. E.\& Tatham, R. L. (2006). Multivariate Data Analysis. New Jersey, USA: Pearson Prentice Hall.

Hausman, A. (2000). A Multi-Method Investigation of Consumer Motivations in Impulse Buying Behavior. Journal of Consumer Marketing, 17(5), 403-419.

Hawkins, D., Mothersbaugh, D.\& Best, R. (2009). Consumer Behavior Building Marketing Strategy (11th Ed.). McGraw-Hill.

Herabadi, A. G., Verplanken, B.\& Knippenberg, A. V. (2009). Consumption Experience of Impulse Buying in Indonesia: Emotional Arousal and Hedonistic Considerations. Asian Journal of Social Psychology, $12,20-31$.

Hirschman, E. C. (1980). Innovativeness, Novelty Seeking, and Consumer Creativity. Journal of Consumer Research, 1, 283-295.

Hirschman, E. C.\& Holbrook, M. B. (1982). Hedonic Consumption: Emerging Concepts, Methods and Propositions. Journal of Marketing, 46, 92-101.

Hoch, S. J.\& Loewenstein, G. F. (1991). Time Inconsistent Preferences and Consumer Self Control. Journal of Consumer Research, 17(4), 492-507.

Iyer, E. S. (1989). Unplanned purchasing: knowledge of shopping environment and time pressure. Journal of Retailing, 65(1), 40-57.

Jarboe, G. R.\& McDaniel, C. D. (1987). A Profile of Browsers in Regional Shopping Malls.Journal of the Academy of Marketing Science, 15(1), 46-53.

Kavak, B. (2008). Pazarlama Araștırmaları Tasarım ve Analiz (Marketing Research Design and Anaylsis). Ankara, Turkey: Hacettepe University.

Kim, H. Y.\& Kim, Y. K. (2008). Shopping Enjoyment and Store Shopping Modes: The Moderating Influence of Chronic Time Pressure. Journal of Retailing and Consumer Services, 15(5), 410-419.

Mano, H.\& Elliot, M. (1997). Smart Shopping: The Origins and Consequences of Price Savings. Advances in Consumer Research, 24, 504-510.

Mano, H.\& Oliver, R. L. (1993). Assessing the Dimensionality and Structure of the Consumption Experience: Evaluation, Feeling, and Satisfaction. Journal of Consumer Research, 20(3), 451-466.

Maslow, A. H. (1968). Toward a Psychology of Being. Princeton N. J.: Van Nostrand.

Moe, w. w. (2003). Buying, Searching, or Browsing: Differentiating Between Online Shoppers Using InStore Navigational Clickstream. Journal of Consumer Psychology, 13(1/2), 29-39.

Murray, E. J. (1964). Motivation and Emotion. Englewood Cliffs, New Jersey: Prentice Hall, Inc.

O’Shaughnessy, J. (1987). Why People Buy. New York, NY: Oxford University Press, Inc.

Park, J.\& Lennon, S. J. (2006). Psychological and Environmental Antecedents of Impulse Buying Tendecy In the Multichannel Shopping Context.Journal of Consumer Marketing, 23(2), 58-68.

Peck, J.\& Childers, T. L. (2006). If I Touch it I Have to Have it: Individual and Environmental Influences on Impulse Purchasing. Journal of Business Research, 59(6), 765-769.

Piron, F. (1991). Defining Impulse Purchasing. Advances in Consumer Research, 18(1), 509-514.

Prasad, V. K. (1975). Unplanned Buying in Two Retail Settings. Journal of Retailing, 51(3), 3-12.

Puccinelli, N. M., Goodstein, R. C., Grewal, D., Price, R., Raghubir, P.\& Stewart, D. (2009). Consumer Experience Management in Retailing: Understanding the Buying Process. Journal of Retailing, 85(1), 15-30. 
Ramanathan, S.\& Menon, G. (2006). Time-Varying Effects of Chronic Hedonic Goals on Impulsive Behavior. Journal of Marketing Research, 18, 628-641.

Rook, D. W. (1987). The Buying Impulse. Journal of Consumer Research, 14(2), 189-199.

Rook, D. W.\& Fisher, R. J. (1995). Normative Influences on Impulsive Buying Behavior. Journal of Consumer Research, 22, 305-313.

Schindler, R. M. (1989). The Excitement of Getting a Bargain: Some Hypotheses Concerning the Origins and Effects of Smart-Shopper Feelings. Advances in Consumer Research, 16, 447-453.

Shao, A. T. (2002). Marketing research : An Aid to Decision Making. Cincinnati, Ohio : SouthWestern/Thomson Learning.

Sproles, G. B.\& Kendall, E. L. (1986). A Methodology for Profiling Consumers' Decision-Making Styles. Journal of Consumer Affairs, 20(2), 267-279.

Tauber, E. M. (1972). Why do People Shop? Journal of Marketing, 36, 46-59.

Thompson, C. J., Locander, W. B.\& Pollio, H. R. (1990). The Lived Meaning of Free Choice: An ExistentialPhenomenological Description of Everyday Consumer Experiences of Contemporary Married Women. Journal of Consumer Research, 17, 346-361.

Tuncer, D., Alkibay, S.\& Hoşgör, Ş. (2008). Turkish Shopping Centers and A Research on the Reasons for their Attraction. International Congress Marketing Trends, 17th-19th January. Venice.

Wakefield, K. L.\& Baker, J. (1998). Excitement at the Mall: Determinants and Effects on Shopping Response. Journal of Retailing, 74(4), 515-539.

Wesley, S., Melody, L. H.\& Woodside, A. G. (2006). Consumer Decision-Making Styles and Mall Shopping Behavior: Building Theory Using Exploratory Data Analysis and the comparative method. Journal of Business Research, 59(5), 535-548.

Westbrook, R. A.\& Black, W. (1985). A Motivation-Based Shopper Typology. Journal of Retailing, 61, 78103.

Wood, M. (1998). Socio-Economic Status, Delay of Gratification, and Impulse Buying. Journal of Economic Psychology, 19(3), 295-320. 